\title{
Instrumentalization of Religious Conspiracy Theories in Politics of Victimhood: Narrative of Turkey's Directorate of Religious Affairs
}

\author{
Ihsan Yilmaz ${ }^{1, *(\mathbb{D})}$ and Ismail Albayrak ${ }^{2}$ \\ 1 Faculty of Arts and Education, Alfred Deakin Institute for Citizenship and Globalization, Deakin University, \\ Burwood, VIC 3125, Australia \\ 2 School of Theology, Faculty of Theology and Philosophy, Australian Catholic University, \\ Melbourne, VIC 3002, Australia; Ismail.albayrak@acu.edu.au \\ * Correspondence: ihsan.yilmaz@deakin.edu.au
}

check for updates

Citation: Yilmaz, Ihsan, and Ismail Albayrak. 2021. Instrumentalization of Religious Conspiracy Theories in Politics of Victimhood: Narrative of Turkey's Directorate of Religious Affairs. Religions 12: 841. https:// doi.org/10.3390/rel12100841

Academic Editor: Paul Morris

Received: 20 August 2021

Accepted: 30 September 2021

Published: 8 October 2021

Publisher's Note: MDPI stays neutral with regard to jurisdictional claims in published maps and institutional affiliations.

Copyright: (C) 2021 by the authors Licensee MDPI, Basel, Switzerland. This article is an open access article distributed under the terms and conditions of the Creative Commons Attribution (CC BY) license (https:/ / creativecommons.org/licenses/by/ $4.0 /)$.

\begin{abstract}
While victimhood has been studied from very different perspectives, the question how secular nation states have instrumentalised religion for the politics of victimhood has not been studied. This paper addresses this gap in the literature on victimhood by analysing the empirical case of Turkey. As is well known, the constitutionally secular Turkish state, first under the rule of the Kemalists and now Erdoganists, has been using the Directorate of Religious Affairs (Diyanet) to propagate the state ideology to the faithful. This paper shows that the Turkish state has recently been using Islam to construct and disseminate a religious victimhood narrative, mainly based on conspiracy theories via the Diyanet's Friday sermons. To do this, the article investigates the texts, such as the sermons produced by the Diyanet that are read verbatim, in every mosque in Turkey during Friday prayers that are attended by more than half of the adult male population. The paper contributes to the victimhood literature by showing how religion, i.e., Islam, has been instrumentalised by a secular state in the construction of an Islamist populist and civilisationist victimhood narrative. Further studies are needed to see if and to what extent the Islamist victimhood narrative of the Turkish state has been impactful on the mosque-goers in the country.
\end{abstract}

Keywords: victimhood; conspiracy theories; populism; civilisationism; sedition; AKP; Diyanet; sermon

\section{Introduction}

From 1887 on, when Nietzsche (2006) wrote about the man of ressentiment as opposed to the noble man, the relationship between the state of victimhood, the desire for revenge, and the will to power has been excessively investigated. While victimhood has been studied from very different perspectives, how secular nation states have instrumentalised religion for the politics of victimhood has not been studied. This paper addresses this gap by analysing how the secular Turkish state under the rule of the Justice and Development Party (the AKP), has been using Islam to construct and propagate a victimhood narrative that is mainly based on conspiracy theories. The Islamist populist (Yilmaz et al. 2021a) AKP has been using different conduits, such as the media, pop culture, movies, TV series, national curriculum, political statements, opinion leaders, and religious leaders. This paper will only look at one of these avenues used by the AKP, the Directorate of Religious Affairs (the Diyanet). The Diyanet monopolistically controls all mosques (about 90,000) in Turkey and employs all imams and preachers (more than 100,000). The Turkish state has used Diyanet sermons as instruments of propaganda since the inception of the institution (Yilmaz 2005; Gözaydin 2020).

To investigate how the secular Turkish state has been using Islam to construct and propagate a victimhood narrative, the paper investigates the Friday sermon texts produced by the Diyanet. Attending Friday prayers is obligatory in Islam for adult males. In Turkey, 
more than half of the adult males regularly attend these prayers. During these prayers, imams deliver a sermon in Turkish that lasts about 10-15 min. Friday sermons are centrally written in the Diyanet headquarters, and they are then read verbatim in Diyanet-controlled mosques in Turkey in addition to the many thousands abroad where Turks live, such as Germany, France, Belgium, the Netherlands, the United Kingdom and Australia. These sermons are always posted on the Diyanet's official website. Every year, the Diyanet produces 54 sermon texts: 52 weekly sermons plus two religious festival sermons.

The Diyanet, as an ideological state apparatus, started its journey as a protector of the Turkish state's understanding of Islam and secularism. The Turkish state and Turkish national identity are based on Turkishness and Islamic identity (Yilmaz 2021a; Y1lmaz et al. 2020). As a result, Islam was institutionalised in the Diyanet. The Diyanet has been included in the constitutions of 1924, 1961 and 1982. The current constitution of 1982 clearly stated in its Article 136 that the Diyanet's main aim is to work for national solidarity and unity. By using the Diyanet, the state has tried to define Islam (Gözaydın 2020). The academic literature on the Diyanet is in consensus on the fact that the Diyanet was hyperpoliticised with the appointment of Mehmet Görmez as its director in November 2010 (Öztürk 2016; Yilmaz and Barry 2020; Yilmaz and Albayrak 2021; Yilmaz and Albayrak 2022; Mutluer 2018; Öztürk and Sözeri 2018; Albayrak 2020). This hyper-politicization was accelerated after the appointment of the current Diyanet director, Ali Erbaş, in 2017 (Yilmaz and Erturk 2021). The literature has shown how like other contexts where populists made use of religion (Yilmaz and Morieson 2021; Yilmaz et al. 2021b; Yilmaz et al. 2021c), the Erdoganist AKP (Yilmaz and Bashirov 2018), fused its populism and Islam (Yilmaz 2018; Yilmaz 2021a; Yilmaz 2021b; Yilmaz 2021c). Diyanet's Islamism and Islamist populism emerged and intensified in parallel with the AKP's increasing anti-Western 'civilisationist' (Brubaker 2017) rhetoric (Bashirov and Yilmaz 2020) and Islamist populism (Akalin 2016; Öztürk 2016; Öztürk and Sözeri 2018; Yucel 2019; Ongur 2020). This paper contributes to this literature on the Diyanet by showing how it also followed in the footprints of the AKP by constructing and/or disseminating Islamist victimhood narrative.

To show how a secular nation state has instrumentalised religion for the politics of victimhood and has been using religion to produce and propagate a victimhood narrative, this paper subjects the Diyanet sermons to qualitative content and discourse analysis. The analysis we offer in this paper is based on these textual resources. We have gathered these Diyanet sermons from its official website; they have been downloaded from different Diyanet webpages over the years. All sermons between January 2001 and July 2021 have been analysed. They have been uploaded to NVivo 12 software for textual, content and thematic analyses. When referring to a specific sermon, the paper will only mention its date.

After explaining the use of victimhood in politics and the AKP's politics of victimhood, the paper will investigate how the sermons followed in the footsteps of the AKP's construction of victimhood. Then, the paper concludes by highlighting the need for future studies on the impact of this narrative on the mosque-goers.

\section{Use of Victimhood in Politics and the Role of Religion}

Every state of victimhood entails an act of victimization, though acts of victimization do not always end in a state of victimhood (Noor et al. 2017). Victimhood identity is not an automatic outcome of being victimized, it is a constructed identity. Collective victimization can be the result of structural or direct victimization (Povinelli 2014; Bağc1 et al. 2018). Being in a state of victimhood can have various consequences for groups' political attitudes (Horwitz 2018).

In societies that experience long-term intractable conflicts, victimhood beliefs become an essential part of the narratives of parties involved in the conflict as members engage in a subjective process of blaming the out-group for the (imagined and/or real) harm, "considering the ingroup as the only victim and the perpetrating outgroup as the immoral and unjust culpable" (Bağ $\mathrm{Cl}$ et al. 2018, p. 95). There is a close link between a sense of victimhood and a belief in conspiracy theories (van Prooijen and Douglas 2018). People's 
collective experience of or imagined victimisation can make them more prone to believing conspiracy stereotypes. After experiencing collectively acts of discrimination, disadvantage, or crimes, groups can develop a theory about out-groups conspiring against the in-group (Bilewicz and Stefaniak 2013; Bilewicz and Sedek 2015). Conspiracy theories are used in this process because of their ability to convey a picture of security, stability, and simple answers (Kinnvall 2004, p. 742). There is a close link between a sense of victimhood and a belief in conspiracy theories as people's collective experience of or imagined victimisation can make them more prone to believing conspiracy stereotypes (Bilewicz and Sedek 2015). After experiencing collectively acts of discrimination, disadvantage, or crimes, groups can develop a theory about out-groups conspiring against the in-group (Bilewicz and Sedek 2015). As nationalism and religion are intimately linked to chosen traumas and chosen glories, they are powerful identity signifiers in times of uncertainty by supplying a consistent structure and simple but comprehensive answers to complex questions (Kinnvall 2004, p. 757).

Victim beliefs and collective victimhood may contribute to sustaining and fuelling conflicts between groups (Albayrak 2013). These beliefs can be created and sustained through powerful and effective stories about past traumas and experiences of victimisation. Religions have long been known as powerful instruments in the formation and maintenance of victimhood narratives. Many religions and religious groups have victimhood narratives. Sometimes, these are employed for political causes. While, it has been well known that states heavily relying on religion such as Iran have been effectively using religious victimhood narratives (anti-Sunni sectarian or anti-Western), however, little is known how secular states also construct, use and propagate religions victimhood narratives. This paper investigates this issue by looking at how Turkey's ruling party, AKP, is using Islam to construct and propagate produce and disseminate its own version of victimhood narrative.

\section{Victimhood Narrative of the AKP in Turkey}

Victimhood narrative has been central to Islamism in Turkey. Turkish Islamist victimhood narrative mainly argues that the Islamists have been "the true 'victims' of the modernisation process in Turkey" (Yilmaz 2017, p. 483). At the heart of their victimhood, the collapse the Ottoman Empire, abolishment of the Caliphate and the establishment of the secular Republic in 1923 have prominent places. The Kemalists have been the main target of this victimhood narrative. Also, persecution of leading Islamist intellectuals paved the way for the emergence of resentment towards the Kemalists and the Turkish Republic among the Islamist intellectuals who saw themselves as "alienated in their own country", and as being forced into "estrangement" and as "pariah" (Aktay 2003; see also in detail Singer 2013). In this Islamist imagination, the history of modern Turkey is framed entirely as a "victimhood of devout Muslims" (Y1lmaz 2017, p. 487).

In the early 2000s, the AKP was able to credibly paint itself as the victim of the Kemalists and secular Turks who were dabbed as the White Turks. As opposed to the White Turks, the Turkish Islamists have presented themselves as the "Black Turks" (Bilici 2009; Demiralp 2012) who have suffered at the hands of the Kemalists.

In the post-Gezi period, AKP internationalised its victimhood, connecting its destiny with the Muslim ummah, another imagined perennial victim (and a morally superior actor). During Gezi Protests, Erdoğan blamed "interest rate lobbies" (this is to say, Jews) and claimed Germany, USA, UK, Otpor! and CNN were the masterminds (Lancaster 2014, p. 1684; Tepeli and Demirok 2014, pp. 71-72). The pro-AKP media was full of wild, fake victimhood examples. Similarly, Erdoğan claimed that "[protesters] were drinking alcohol in the mosque and doing much worse". In short, Erdoğan and the AKP re-embraced the Turkish Islamist victimhood narrative but mixed it with the Kemalist victimhood narrative that the country, state and nation were victims of an international conspiracy led by the West and its local puppets. Hence, from 2013 on, AKP has depicted every election as 'war of independence' (Parlak and Uz 2015, p. 69). 
Islamist victimhood allows the AKP to present itself both as the victim of Western conspiracies and as the leading defender of Turkey and the entire Muslim world against such conspiracies at the same time. These so-called attacks against the Turkish Islamists are considered to be directed against the Muslim World as well. In this narrative, even the most negligible loss of AKP means a huge blow to the Muslim world.

\section{Emergence of Conspiracy Theories in the Diyanet Sermons and the Warning of Fitna (Sedition)}

Fitna has been one of the most useful religious concepts employed in the sermons when Erdoğan and AKP need of relieving a governmental accountability for their major failure in certain issues. This concept has different meanings, but as it is used in the Diyanet sermons, it generally corresponds to the corruption, separatism, sedition, provocation, and rebellion against a "rightful leader". In general, the concept of fitna is used in the sermons to conceptualize a current situation, or to describe a hardship the Islamic world faced or a form of behaviour that Muslims are advised to stay away from. However, it is also used to conceptualize the situation caused by an ambiguous agent within a certain plan in reference to a certain event. The frequency of use of this concept in sermons over the years is parallel to Diyanet's institutional transformation and the process of repositioning itself in the politically.

When the process of the last decade is examined, it is seen that the concept of fitna was not used frequently in sermons before 2014, but it was increasingly used after 2014. In fact, we have almost never encountered the Qur'anic term fitna (sedition) in connection with specific enemy, in the sermons before the Görmez-Erbaş era. During this period, the concept of fitna was used in 78 sermons. Diyanet has utilised this concept (fitna) in explaining incidents and developments that have shaped the last decade of the country such as Gezi Park Protests, 17-25 December corruption investigations and increasing terrorist attacks to the public. For example, in 2020 on the occasion of the 2016 mysterious coup attempt anniversary the sermon read, "It should be known very well that the FETÖ (refers to Gülen Movement (GM) as a terrorist organisation), which attempted against the sovereignty and future of our nation on 15 July, is a network of corruption and corruptors" (10 July 2020). As indicated above, after 15 July coup, this term has become an inseparable part of the sermons. Although the textual and historical context in which the verses related to these concepts (fitna and fasād/sedition and corruption) take place is very different from the current usage of the Diyanet, it is worth noting that two of the most vivid verses on this subject are verses 11-12 of Surah al-Baqara: "And when it is said to them, 'Do not cause corruption on the earth', they say, 'We are but reformers'. Verily! They are the ones who make mischief, but they perceive not". These two verses occur in the sermons dated 29 July 2016; 13 July 2018; 9 July 2021 as a heading of the sermons whereas their meaning is given in the sermons dated 12 July 2019 and 10 July 2020. These two verses have been used in sermons every year after 2016. Additionally, verses from Surah al-Māida (5:32) and Surah al-Rūm (30:41) are mentioned in the same context, namely fitna and fasād. From Qur'anic perspective, the subject discussed in these verses are very different from Diyanet's sermons. The verses in question (2:11-12) show the situation of the hypocrites in Madina, but the Diyanet did not hesitate in the sermons to patch this attribute to a movement whose volunteers reached millions both in Turkey and abroad. Interestingly, the interpretation of the relevant verses (2:11-12) in the official commentary published by the Diyanet is as follows:

Every person likes his own reason/intellect and claims that the path he follows is correct. When it comes to the proof of the claim, the difference between the believer and the unbeliever emerges. The evidence of a believer is the revelation, which is next to his reason, even in front of him, and which is the source of true knowledge, the information and explanations in the Qur'an and hadiths. Those who do not believe in the Prophet have to be content with only human intellectual capacities and sources. Since the sources of human knowledge (intellect) are not 
sufficient to find and know the truth on many issues, those who are content with this make mistakes and go astray; but because they do not know the truth, they insist on arguing that what they know and do is absolutely right. Those who do not believe in the true religion only partially realize that they are wrong in understanding of the super-rational matters (things beyond the comprehension of the intellect and needs for revelation). They can only understand their mistake when they are stuck in a dead end, their systems are clogged, and depressions arise. (Karaman et al. 2020, I. pp. 80-81).

Clearly, there is nothing related to the Gülen movement or any other identified or unknown enemies in the aims of Diyanet's official exegesis of these verses. Diyanet is arguing that the real victim is the Turkish people (including Erdoğan, AKP and its supporters) by choosing verses with heavy theological implications. The most natural consequence of the use of religion and theological language in the name of attacking dissidents in such an arbitrary way allows Diyanet to criminalise all dissidents.

The term fitna is quite flexible and can encompass a range of meanings depending on how the sermon contextualises it. In the sermons before 2015, the concept of fitna is used without referring to any perpetrator but in general referring to all sort of calamities facing the Muslims. For example, in a sermon dated 4 October 2014, "Believers should be alert to all kinds of fitna, the chaos, uneasiness and disasters that will bring about it, they should oppose all these with prudence and foresight, and should not allow them" (4 October 2014).

On the other hand, it is also worth mentioning that particularly after June 2015 general elections, the period when the peace talks between the state and Kurdish insurgents were suspended and acts of violence and terror showed dramatic increase, the concept of fitna has been used to refer to those perpetrators of terrorist activities. In this context, a sermon dated July 2015 and titled "Today is the day of unity and amity" described the acts of terrorism that took place in Turkey as an extension of a global war, and therefore inevitable. The sermon reads as follows:

Our country is also affected from time to time by a great war on a global scale, which is staged to stir a great fitna. [People of] Our nation who have been brothers, neighbours, and lived side by side hand in hand for centuries, is wanted to be turned against each other. On the other hand, our duty is to never give an opportunity to those who try to sow seeds of fitna and sedition in our beautiful country. It is always to be prudent against this great and cruel game. It is to act with precision. The day is the day to bond with each other" (24 July 2015).

In the following period, the spiral of violence, which Turkey has fallen into, was explained to the congregation with similar rhetoric. Terms such as "game", "tricks" and "trap" have been added to the concept of fitna and the perception of "victimhood" has been strengthened. In addition, with the terms such as "centres of evil" and "[foreign] forces," the perpetrator(s) have been attributed a more mysterious and ambiguous character. This attributed "ambiguity" to the perpetrator(s) has also performed many different functions. The most practical function/utility of this mentioned "ambiguity" has been its power to easily relate any existing or potential opposition, any sort of negativity or socio-economic deterioration to a "network of evils" and avoid responsibility in the eye of public. In this context, the following statements were made in a sermon in 2015:

"We have never given an opportunity to those who want to destroy our brotherhood, unity, solidarity, and strength with strife and hostility. It is our duty to all of us in these difficult days, when our heart-breaking events are experienced, once again, it is to hold each other tightly; not to allow games played on our religion, our beautiful country, our nation and our brotherhood" (21 August 2015).

After a few months a sermon dated 15 January 2016 noted that the terrorist actions in Turkey caused by fitna and perpetrators of these acts, the PKK and the ISIS, are guided by some certain "[foreign] forces". The relevant part of the sermon reads as follows: 
"Today, as a country, as a nation, we are going through the heaviest tests. The fire of strife is fuelled with all its violence every day by those who mean our unity and want to set us against each other. Many of our brothers and innocent people die with the treacherous attacks caused by sedition and the limitless savagery of those who have lost their conscience and mercy. An understanding that justifies all kinds of violence and murder, with the fanaticism stemming from ignorance and guided by certain outbreaks, stabs our hearts day by day like a dagger" (15 January 2016).

A similar discourse is used in a sermon from the same year and attention is drawn to the size of the threat Turkey faces and the congregation is urged to keep the unity and solidarity against this emerging threat with the following words:

"Let's never forget that terrorism and its evil forces that use it all mean our country, our nation, our sacred and our future. As long as we should be alert to all kinds of mischief, deceit, trap and game. Let's stay away from any kind of discourse and action that will harm the love and brotherhood between us. Otherwise, let's never forget that we will be a tool for terror and the dark centres that direct it" (18 March 2016).

In explaining causes of violence and acts of terrorism Turkey has been exposed to, addressing the congregation, the sermon emphasised that Turkey has an exceptional place and position in the world politics and with this it gives hopes to all the victims and the oppressed in this respect. It is also put stress that because of this, Turkey has been the target of "centres of evil" and exposed to their attacks. In this regard what we observe as the role of Diyanet in contemporary Turkey is emphasising and exaggerating an enemy, might be real or imagined, and directly or indirectly referring/addressing the current regime as the safe haven against this enemy as an act of survival. In this regard the sermon in 2015 highlight the following:

"Today, we are going through a difficult process and a heavy test. While the war begins where our borders end, millions of people fleeing persecution take refuge in our homeland, there are those who want to draw us into the ring of fire. There are those who want to pit us against each other, to weaken our strength, to hurt brothers and sisters. There are those who attempt to intimidate, harass, divide and destroy this beloved nation with their dark tricks. There are evil forces who exploit our children for their treacherous ambitions, kidnap our daughters from their mothers and take our sons off their fathers. There are those who try to defeat religion and put grudge and hatred on their tongue and sow hate seeds in the land of peace" (11 September 2015).

With these words, as well as acts of terrorism and violence, the refugee crisis too is linked to/accused of ambiguous external enemies/forces. Then with the following words the attitude to be taken against such an "ambiguous" enemy is suggested:

"Our beloved nation is aware of all the events with its vast foresight. It is the nature of this nation to continue to be a beacon of hope to the world by preserving its strength and integrity," it is advised on the attitude to be taken against this 'ambiguous' enemy" (11 September 2015).

In a similar manner, in a sermon dated 23 December 2016 to convince the congregation that the leadership of the country is on the right path and should continue on this path, it is urged that "the evil forces" targeting Turkey's "independence and the future," aims to stop Turkey from being the "hopes of the victims and oppressed around the world". Therefore, the sermon urges, with this consciousness, Turkey should not give up being with "the good against the evil; with the oppressed against the oppressors" (23 December 2016). As evidently seen in the sermons, it is constantly emphasized that every problem that grows in the country and has become almost insoluble, is externally sourced. In this blame game to avoid the leadership from the responsibility, Diyanet emerges and comes as a 
godsend to save the situation and convince the conservative people by twisting words from religious resources. With the aid of Diyanet, victimhood has become a constitutive selfunderstanding of Turkey. This victimhood created by Diyanet is the ontological character of Turkish people. In pure theological terms, Turkey's victimhood, like Erdoğan's, is destiny itself.

\section{The Source of the Fitna, Victimhood and Conspiracies in the Diyanet Sermons}

Following the mysterious July 15 coup attempt, the AKP's strategy excessively focused to explain negative developments with conspiracy theories supposedly at work in a country and society. The tone of these sermons is highly anti-Western and nationalist conservative. This discourse has been promulgated to externalized to blame to "the others". In this context, in addition to the concept of fitna, which is used to explain the challenges facing the country. The challenges such as "the country's survival is under threat," or "homeland is targeted by evil forces" are employed in the sermons in a way that blur the line between reality and imagination. The notion of surrounded by enemies from all sides is frequently comes to fore. As it is known, Erdoğan and AKP officials have thrown all kinds of blames and negativities in the country on others. With such a move, Erdoğan does not just avoid taking responsibility, at the same time, he himself becomes the victim of these negativities. We witness that the Diyanet carries a similar perception to the religious field through sermons.

According to AKP, the only perpetrator of the coup attempt is the GM, but the role of the movement in the coup does not go beyond being a pawn. According to this narrative, external forces supported the GM and used it for the coup. Therefore, according to official narrative, this incident is an attempt to occupy and an attack on the survival of the nation. While it can be understood that foreign powers here mean the USA, countries such as Germany and Britain can sometimes even be included along with Arab countries where the AKP has problems in foreign policy. Nevertheless, the AKP's rulers often leave ambiguous what they mean by external forces, thus gaining flexibility in adapting the concept of "external powers" to different periods and events.

The systematic marginalization of AKP opponents through Diyanet sermons has led to the exclusion of these victimised groups from the moral community by the seemingly ethical-religious authority, namely Diyanet.

Diyanet has also played an important role in delivering the official discourse on July 15 to the public. In the weeks and anniversaries following the coup attempt, Friday sermons were read on this issue, and the failed coup was described as an effort targeting "the existence, peace, unity and solidarity of the nation", and actions of "a great betrayal and invasion". As for the failure of the coup attempt sermons read, "We were saved from rolling into the pit of fire and sinking into darkness," and the sermon continues, "our nation did not allow the enemy to violate and trample over its land, dignity and honour [ .....] we came back from the brink of a great disaster" and "we did not allow the invasion attempt" (22 July 2016). In this context, the following statements were made in another sermon from 2016:

"It should be known that; These treacherous attacks targeting the existence, peace and trust, unity and solidarity of our nation, will never discourage our beloved nation and will never reach its goal. We believe that; Our nation will overcome these difficulties with its faith, spirit of unity and solidarity, and foresight. May our Almighty Lord make our unity, solidarity, and brotherhood forever. May the wrath of God Almighty be upon all the traitors, oppressors and evil focuses who mean our values" (19 August 2016).

The failure of the coup attempt was also told to the public with religious and historical references. By adding a sublime/holy dimension to the events that took place that night, it was aimed to accept many contradictions on this issue without questioning. In this context, the sermon read on the first anniversary of July 15 says, "O believers! Remember Allah's blessing to you. When a group tries to reach you and Allah shies away from you. Avoid 
going against Allah. You should trust and trust only in Allah". The following statements are given by quoting:

"In fact, this verse is the verse that was revealed to explain how Almighty Allah confirmed and supported the Islamic army with his angels in the Battle of the Trench. However, this promise of God continued to come true at many turning points in history. This promise of God came true in Manzikert, Çanakkale. It was accrued in Sakarya, Dumlupinar. And we, as a nation, witnessed once again that God's promise was fulfilled on July 15, a year ago. That night, as a country and nation, we were subjected to a great betrayal and occupation attempt. In this dark night, we once again observed that Allah did not spare us His grace and mercy, his help and grace" (14 July 2017).

Effectively, jingoism and religious rhetoric have been merged with the sermons' sensationalist and conspiracy-ridden tone to explain events of political significance. Another sermon close to the coup anniversary reads, "let us remain conscious, have common sense, and be resolute. Let us not give any opportunity to those who try to abuse and exploit our national and spiritual values" (10 July 2020). The references to "those" and "exploitation" effectively add ambiguity and at the same time directs the blame of concurrent events to "the others". We also witness here that Diyanet, under the shadow of the AKP, secretly injects Turkey's elite position and the Turkish government's supremacy role into the community in a well-adjusted dosage.

This pattern is also visible when AKP's foreign policy is supported by these accounts painted by the Diyanet. One prominent example is the justification for AKP's involvement in Syrian war. According to the Diyanet, the fitna from overseas along with their domestic collaborators are creating malice at home and the government has taken a stance to "protect" its citizens. Effectively the money spent on the war, deteriorating ties and loss of life are all justified through this narrative.

In recent years when Turkey has been directly involved in Syrian crisis these themes are frequent. As a result of this involvement the Erdoğan's government has launched several military operations in Syrian territory. The Diyanet under the guidance of the AKP regime launched an intense propaganda campaign in relation to religious requirements of these operations. Addressing the criticism against Turkey's involvement in the Syrian crisis, Diyanet conveyed the message that these operations are for "Turkey's survival". It justified the actions taken in Syria as necessary to eliminate the threats against the territorial integrity/unity of the country and to help those "oppressed by terrorism". These points were explained to the public with Islamic references such as jihad intertwined with conspiracy theories, and the Diyanet played an active role in these propaganda activities. Like many jihadist (Hodge 2020, p. 69), the sense of "absolute victimization" is intrinsic to AKP. Erdoğan and AKP, which has become increasingly isolated in world and regional politics, identifies the West together with its internal collaborators as the culprit for its fatal mistakes in its Syria policy. The biggest victim in these policies is the Turkish people, whom they think they represent.

In this context, another interesting point in the sermons is that the sermons highlight that the enemy facing Turkey is not limited to the visible enemies, and as part of a "big game" Turkey is targeted by "evil forces". Therefore, an attempt is made to create the perception that the government cannot be held responsible for negative developments facing Turkey. The public is encouraged to support the government's operations and to show unity and solidarity. In sermons delivered after the controversial Olive Branch, which was an operation launched against Afrin, the Kurdish enclave in Northern Syria, this idea is overtly visible. The sermons and the AKP have presented this operation as a "matter of survival". The following statements were made in this context:

"In recent years, we have been passing through the circle of testing both as the ummah of Islam and as a nation. Those who want to weaken our power and set brothers against brothers come to us with the weapon of fitna, terror and 
betrayal. Our country is trying to be drawn into the fire pits opened in all corners of the Islamic geography. Our existence and survival, our independence and our future are targeted with various tricks and deceptions, plans and traps. By threatening our unity and vitality, the hopes of the Muslim ummah are actually being consumed" (20 January 2018).

The self-righteous assertion of Diyanet and Erdogan does not only seek the rights of victims in Turkey, but also takes action to heal the wounds of the entire victimised ummah. Here it can be seen that a win-win situation has been created ingeniously. We are faced with the scenario of Erdogan, who bears the suffering and grievances of years and acts with the power of innocence created by common wounds. As it is mentioned in some Arab media, the Anatolian Lion (Erdogan) has turned into the saviour of the Ummah with the contribution of Diyanet sermons. Interestingly, on the one hand, a superior AKP government and a strong Ummah leader emerged through the Diyanet's victimhood discourse, which does not associate any of the problems encountered with the existing administrative mechanism. In other words, the perception of victimhood, which Erdogan and Diyanet keep on the agenda, has also turned into an empty and hollow supremacy. This gives the great masses the feeling that they are rising even though they are in a deep socio-economic and political collapse, and it consoles them. In this context, it is necessary to draw attention to another aspect of the Diyanet's victimhood discourse. It is seen that it has fulfilled an important mission, such as fighting against the enemies for centuries and the perception of being surrounded by enemies on all sides, camouflaging daily problems and all kinds of undemocratic practices of the current government through sermons. As can be seen in the excerpts from the sermons above, Diyanet, which keeps constantly the phenomenon of sedition and testing alive, has set up a mechanism in its own way not to show or remind the mosque community of the numerous problems in real politics. A similar message is also given in a sermon during the same year:

"Today, we need to have a sense of victory against the attempts to suppress our country and encircle the Islamic geography. Awareness of victory is bearing with and enduring the difficulties. It is to put aside the conflicts, discussions and passions that gnaw away this society, which resembles a giant plane tree with deep roots. Being alert to those who want to shake our brotherhood and spoil our conversation" (24 August 2018).

As the war in Syria intensified the messaging through the sermons remained persistent. Over a year later, in 2019, a similar narrative is repeated in a sermon titled "Day is the day of unity and solidarity". This sermon overlaps in terms of its timings with the government's decision to start Peace Spring Operation to build a safe haven in north of Syria. The congregation is told:

“Unfortunately, today's world has been turned into a place where dark traps are set. Innocent people were driven out of their homes, lifeless bodies of young children washed up on the beaches. Those who want to open fire pits in all corners of the Islamic geography have set brother against brother with weapons of sedition, terror, and betrayal. Our existence and survival, our independence and our future have been targeted with various tricks and deceptions, plans and traps" (11 October 2019).

For the Turkey's activities in Syria, on the other hand, to convey the politically instrumentalised perception of threat against Turkey, the nationalist rhetoric is also employed alongside Islamist victimhood narrative:

"As a nation, we passed through great troubles and heavy tests. Just yesterday in Çanakkale, Sakarya and Dumlupınar, the evil forces with no mercy and humanity waged war on us to wipe us from the stage of history. We were subjected to one of the biggest betrayals of our history on July 15th. We had tremendous strength that made us victorious in these difficult days. This power was our unwavering 
faith in God. It was our love for homeland, adhan, flag and independence. Being martyrdom and veteran was our love" (26 January 2018).

The past sufferings and victimhood (Çanakkale, Dumlupınar, etc.) revived with sermons are a new visa and approval for any attack to be carried out against the opposition. In this setting, the following statements were made in a sermon in 2019:

"As a nation, we passed through many troubles. Those who want to erase us from the stage of history have never given up on these ambitions. However, those who covet our homeland, whose every inch of land is watered with the blessed blood of our martyrs, and those who want to disrupt our nation, are doomed to lose today as they did yesterday. Because we have a tremendous power that makes us successful against our enemies. This is our strength, our unwavering faith in Allah, our devotion to the religion of Islam, our love for our homeland, adhan, flag and independence" (11 October 2019).

Similar statements can be found in the sermon read after the death of more than 30 TAF members because of the attack of the Syrian army during the TAF's Idlib operation:

"As a nation, we are going through great troubles today, as we were yesterday, and we are giving heavy tests. As in the Dardanelles and the War of Independence, today we are fighting a relentless struggle against the forces whose conscience is atrophied, who have lost their mercy and humanity, and those who want to erase us from the stage of history. Again, as it was yesterday, we will not let down our flag with every member of our nation, men, women, young and old, and we will not let our prayers fall, we will not tramp our country" (28 February 2020).

These sermons emphasize that the homeland, flag and adhan would be protected against those who want to wipe this nation from the stage of history and covet the homeland. In such an atmosphere, if we define it in religious terminology, every step or security measure to be taken against the opposition or so-called enemies by Turkish government becomes legitimate and lawful, halal.

\section{Conclusions}

In societies that experience long-term conflicts, victimhood beliefs become an essential part of the political narratives where different group engage in a subjective process of blaming the out-group for the (imagined and/or real) harm. People's collective experience of or imagined victimisation make them more prone to believing conspiracy theories. Nationalism and religion have long been observed to be linked to victimhood narratives as well as conspiracy theories. While it has been well known that states heavily relying on religion, such as Iran, have been effectively using religious victimhood narratives, how secular states also construct, use and propagate religions victimhood narratives is under-researched. This paper has addressed this gap in the literature by investigating and showing how a constitutionally secular state is using religion to construct and propagate a victimhood narrative that mainly employs conspiracy theories.

The paper has shown that the Friday sermons have been using the notions of politics of victimhood and victimhood of politics that were connected to each other in light of the concept of fitna (sedition). To do so, the concept of sedition is expanded by the Diyanet, and it is emphasized that the so-called games played on the country, the traps and the attacks of the dark forces will be only overcome with the solidarity of the nation and state. In this regard, the sermons target religious-national feelings on the one hand, and bring issues such as the homeland, flag, call to prayer and independence that the people care about. Friday sermons are now constantly spreading exaggerate accounts and at time false information regarding Turkey's and the ummah's constant struggle with these forces. Ideas such as being forced into "pits of fire" and "evil" posing unpresented dangers for "the faithful" or "the pure" has helped sensitize the audiences to the need of military intervention in regions such as Syria. Consumed in diabolic and fervours flames kindled 
by "the enemies", the people of "the faith" and the land of Anatolia are always in danger, according to Diyanet. The ummah and the Turkish people must always be ready to face tests that are godsend and fitna induced. Under such belief systems the AKP government is provided a "free pass" to carry out its authoritarian policies in the domestic realm as well as the international arena.

Since the main aim of this paper was to study how the victimhood narrative is constructed by using religion in a secular state, it did not look at the questions if and to what extent the Diyanet's instrumentalization of religion in victimhood politics has been helpful for the AKP and how much impact this narrative has had on the population. While it is well known that religiosity in Turkey is in decline, we do not know if the AKP's and Diyanet's victimhood narrative has radicalised some of the congregation. Even if the number of this probably radicalised people may not be high, the negative impact of their radicalised worldview could be catastrophic for the social cohesion and peaceful co-existence in the country. Future research based on field study that would investigate the impact of the Diyanet's victimhood narrative on the mosque-goers would greatly contribute to our understanding of the real impact of the Diyanet's novel religious victimhood narrative.

Author Contributions: Data curation, I.Y. and I.A.; Formal analysis, I.Y. and I.A.; Writing-original draft, I.Y. and I.A.; Writing-review \& editing, I.Y. and I.A. All authors have read and agreed to the published version of the manuscript.

Funding: This research received no external funding.

Institutional Review Board Statement: Not applicable.

Informed Consent Statement: Not applicable.

Data Availability Statement: Not applicable.

Conflicts of Interest: The authors declare no conflict of interest.

\section{References}

Akalin, Ömer. 2016. The Change in Official Islam in Turkey: An Analysis of Friday Sermons Published by the Presidency of Religious Affairs. Istanbul: Sabanc1 University.

Aktay, Yasin. 2003. Diaspora and Stability Constitutive Elements in a Body of Knowledge. In Turkish Islam and Secular State: The Gülen Movement. Edited by M. Hakan Yavuz and John L. Esposito. Syracuse: Syracuse University Press, pp. 133-140.

Albayrak, Ismail. 2013. "The Other" Among Us: The Perception of Khārijī and Ibāḍī Islam in the Muslim Exegetical Traditions. AnkaraÜniversitesi İlahiyat Fakültesi Dergisi 54: 35-63.

Albayrak, Ismail. 2020. Friday Sermons and the Notion of Pulpit Imperialism: Marginalisation of the Opponents with Special Reference to the Gülen Movement. International Journal of Social Science 4: 149-84.

Bağcl, S. Çiğdem, Z. Ecem Piyale, Sevgi Karaköse, and Ezgi Şen. 2018. Collective victimhood beliefs among majority and minority groups: Links to ingroup and outgroup attitudes and attribution of responsibility for conflict. International Journal of Intercultural Relations 66: 95-117. [CrossRef]

Bashirov, Galib, and Ihsan Yilmaz. 2020. The rise of transactionalism in international relations: Evidence from Turkey's relations with the European Union. Australian Journal of International Affairs 74: 165-84. [CrossRef]

Bilewicz, Michal, and Grzegorz Sedek. 2015. Conspiracy Stereotypies. In The Psychology of Conspiracy. Edited by Michal Bilewicz, Aleksandra Cichocka and Wiktor Soral. London: Routledge.

Bilewicz, Michał, and Anna Stefaniak. 2013. Can a victim be responsible? Antisemitic consequences of victimhood-based identity and competitive victimhood in Poland. In Responsibility: An Interdisciplinary Perspective. Warsaw: Matrix.

Bilici, Mücahit. 2009. Black Turks, White Turks: On the Three Requirements of Turkish Citizenship. Insight Turkey 11: $23-35$.

Brubaker, Rogers. 2017. Between nationalism and civilizationism: The European populist moment in comparative perspective. Ethnic and Racial Studies 40: 1191-226. [CrossRef]

Demiralp, Seda. 2012. White Turks, Black Turks? Faultlines beyond Islamism versus Secularism. Third World Quarterly 33: 511-24. [CrossRef]

Gözaydın, İştar. 2020. Diyanet: Türkiye Cumhuriyeti'nde Dinin Tanzimi. Istanbul: İletişim.

Hodge, Joel. 2020. Violence in the Name of God: The Militant Jihadist Response to Modernity. London: Bloomsbury Academic.

Horwitz, Robert B. 2018. Politics as Victimhood, victimhood as Politics. The Journal of Policy History 30: 552-74. [CrossRef]

Karaman, Hayreddin, Mustafa Çağrıcı, İbrahim Kâfi Dönmez, and Sadrettin Gümüş. 2020. Kur'an Yolu Türkçe Meal ve Tefsir. Ankara: Diyanet. 
Kinnvall, Catarina. 2004. Globalization and Religious Nationalism: Self, Identity, and the Search for Ontological Security. Political Psychology 25: 741-67. [CrossRef]

Lancaster, Caroline. 2014. The Iron Law of Erdogan: The Decay from Intra-Party Democracy to Personalistic Rule. Third World Quarterly 35: 1672-90. [CrossRef]

Mutluer, Nil. 2018. Diyanet's Role in Building the 'Yeni (New) Milli' in the AKP Era. European Journal of Turkish Studies 27: 1-14. Available online: https:/ / doi.org/10.4000/ ejts.5953 (accessed on 23 June 2021).

Nietzsche, Friedrich. 2006. On the Genealogy of Morality. Cambridge: Cambridge University Press.

Noor, Masi, Johanna Ray Vollhardt, Silvia Mari, and Arie Nadler. 2017. The social psychology of collective victimhood. European Journal of Social Psychology 47: 121-34. [CrossRef]

Ongur, Hakan O. 2020. Performing through Friday khutbas: Reinstrumentalization of Religion in the New Turkey. Third World Quarterly 41: 434-452. [CrossRef]

Öztürk, Ahmet Erdi. 2016. Turkey's Diyanet under AKP Rule: From Protector to Imposer of State Ideology? Southeast European and Black Sea Studies 16: 619-635. [CrossRef]

Öztürk, Erdi Ahmet, and Semiha Sözeri. 2018. Transformation of the Turkish Diyanet both at Home and Abroad: Three Stages. European Journal of Turkish Studies 27: 1-14. Available online: https:/ / doi.org/10.4000/ ejts.5944 (accessed on 23 June 2021).

Parlak, İsmet, and Pınar Uz. 2015. Mağdur/Mazlumdan Mağrur/Muktedire 30 Mart Seçimleri. Düşünen Siyaset 30: 69-106.

Povinelli, Elizabeth A. 2014. Histories of Victimhood: Assemblage, Transaction, and Figure. In Histories of Victimhood. Edited by Steffen Jensen and Henrik Ronsbo. Philadelphia: University of Pennsylvania Press.

Singer, Sean R. 2013. Erdogan's Muse: The School of Necip Fazıl Kısakurek. World Affairs 176: 81-88.

Tepeli, Ayten Deniz, and İpek Demirok. 2014. Kaygıdan Komploya: Psikoloji Teorileri Açısından Komplo Teorilerine Dair Bir İnceleme. Teorik Bakış 5: 46-74.

van Prooijen, Jan-Willem, and Karen M. Douglas. 2018. Belief in conspiracy theories: Basic principles of an emerging research domain. European Journal of Social Psychology 48: 897-908. Available online: https:/ /doi.org/10.1002/ jsp.2530 (accessed on 23 June 2021). [CrossRef] [PubMed]

Yilmaz, Ihsan. 2005. State, Law, Civil Society and Islam in Contemporary Turkey. Muslim World 95: 385-411. [CrossRef]

Yilmaz, Ihsan. 2018. Islamic Populism and Creating Desirable Citizens in Erdoğan's New Turkey. Mediterranean Quarterly 29: 52-76. [CrossRef]

Yilmaz, Ihsan. 2021a. Creating the Desired Citizen Ideology, State and Islam in Turkey. Cambridge: Cambridge Univeristy Press.

Yilmaz, Ihsan. 2021b. The AKP's Authoritarian, Islamist Populism: Carving out a New Turkey. ECPS. Available online: https: //www.populismstudies.org/the-akps-authoritarian-islamist-populism-carving-out-a-new-turkey (accessed on 23 June 2021).

Yilmaz, Ihsan. 2021c. Erdogan's Political Journey: From Victimised Muslim Democrat to Authoritarian, Islamist Populist. ECPS. Available online: https:/ / www.populismstudies.org/erdogans-political-journey-from-victimised-muslim-democrat-to-authoritarianislamist-populist/ (accessed on 23 June 2021).

Yilmaz, Ihsan, and Ismail Albayrak. 2021. Religion as an Authoritarian Securitization and Violence Legitimation Tool: The Erdoğanist Diyanet's Framing of a Religious Movement as an Existential Threat. Religions 12: 574. Available online: https://doi.org/10.339 0/rel12080574 (accessed on 23 June 2021). [CrossRef]

Yilmaz, Ihsan, and Ismail Albayrak. 2022. Populist and Pro-Violence State Religion: The Diyanet's Construction of Erdoğanist Islam in Turkey. Cham: Palgrave Macmillan.

Yilmaz, Ihsan, and James Barry. 2020. Instrumentalizing Islam in a "Secular" State: Turkey's Diyanet and Interfaith Dialogue. Journal of Balkan and Near Eastern Studies 22: 1-16. [CrossRef]

Yilmaz, Ihsan, and Galib Bashirov. 2018. The AKP after 15 years: Emergence of Erdoğanism in Turkey. Third World Quarterly 39: 1812-30. Available online: https:/ / doi.org/10.1080/01436597.2018.1447371 (accessed on 23 June 2021). [CrossRef]

Yilmaz, Ihsan, and Omer F. Erturk. 2021. Pro-Violence Sermons of a Secular State: Turkey's Diyanet on Islamist Militarism, Jihadism and Glorification of Martyrdom. Religions 12: 659. [CrossRef]

Yilmaz, Ihsan, and Nicholas Morieson. 2021. A Systematic Literature Review of Populism, Religion and Emotions. Religions 12: 272. Available online: https: / / doi.org/10.3390/rel12040272 (accessed on 23 June 2021). [CrossRef]

Yllmaz, Ihsan, Mehmet Efe Caman, and Galip Bashirov. 2020. How an Islamist Party Managed to Legitimate Its Authoritarianisation in the Eyes of the Secularist Opposition: The Case of Turkey. Democratization 27: 265-82. [CrossRef]

Yilmaz, Ihsan, Erdoan Shipoli, and Mustafa Demir. 2021a. Authoritarian Resilience through Securitisation: An Islamist Populist Party's Co-optation of A Secularist Far-Right Party. Democratization. [CrossRef]

Yilmaz, Ihsan, Nicholas Morieson, and Mustafa Demir. 2021b. Exploring Religions in Relation to Populism: A Tour around the World. Religions 12: 301. [CrossRef]

Yilmaz, Ihsan, Mustafa Demir, and Nicholas Morieson. 2021c. Religion in Creating Populist Appeal: Islamist Populism and Civilizationism in the Friday Sermons of Turkey's Diyanet. Religions 12: 359. [CrossRef]

Yllmaz, Zafer. 2017. The AKP and the spirit of the 'new' Turkey: Imagined victim, reactionary mood, and resentful sovereign. Turkish Studies 18: 482-513. [CrossRef]

Yucel, Salih. 2019. Human Rights and Guilt by Association: Said Nursi's Renewal Approach. Australian Journal of Islamic Studies 4: 19-33. 